\title{
FISH COMMUNITIES OF TWO TIDAL CREEKS IN THE PINHEIROS BAY, STATE OF PARANÁ, SOUTHERN BRAZIL
}

\author{
OLIVEIRA NETO, J. F. ${ }^{\text {; }}$ SPACH, H. L. ${ }^{2}$; SCHWARZ JR, R. ${ }^{2}$ \& PICHLER, H. A. ${ }^{2}$ \\ 1 - Curso de Pós-Graduação em Ciências Biológicas - Zoologia/UFPR. Setor de Ciências Biológicas - \\ Depto. de Zoologia. Caixa Postal 19020 - CEP 81531-980 - Curitiba - PR. \\ 2 - Centro de Estudos do Mar - UFPR. Av. Beira-mar s/n. Caixa Postal/P.O.Box 50.002 CEP: 83255-000 - \\ Pontal do Sul Pontal do Paraná - PR - BRASIL.
}

\begin{abstract}
Oliveira Neto, J. F.; Spach, H. L.; Schwarz Jr, R. \& Pichler, H. A. 2010. Braz. J. Aquat. Sci. Technol. 14(2): 47-54. ISSN 1808-7035. Tidal creeks are meandering channels that are highly influenced by tidal changes and can experience substantial variation in salinity and depth over the course of the same day. The goal of the present work is to survey the ichthyofauna associated with these environments and to assess seasonal differences in their composition in tidal creeks of the euhaline sector of the estuary of the Paranaguá. Two tidal creeks of the Pinheiros bay were sampled monthly at the same time using fyke nets. A total of 13,755 fish from 55 species and 27 families were captured. Only the clupeiforms Anchoa parva, Cetengraulis edentulus, and Harengula clupeola showed substantial seasonal variation in abundance, being most frequent during the fall and its adjacent months. Benthophagic individuals such as Sphoeroides testudineus, Bairdiella ronchus and Cathorops spixii were the most dominant in terms of biomass and were present all year long, although with irregular abundance. Sciaenid species were most frequent in the fall and winter, both as juveniles and as adults. The spring and part of the fall were characterized by the highest number of species with mature gonads, whereas the fall was the most important recruitment period, causing an increase in the richness indices and in the number of captured individuals. Tidal creeks were intensively visited by fish of all trophic levels and ages. These results, together with the high richness and diversity indices, corroborate the importance of tidal creeks for the preservation of estuarine environments.
\end{abstract}

Keywords: Seasonality, Sphoeroides, Engraulidae, juveniles, Rypticus.

\section{INTRODUCTION}

The study and preservation of estuarine environments has become a priority, not only due to strong habitat degradation, but also because it is an important habitat for the survivorship and reproduction of a variety of fish species, including those of economic importance (Hoss \& Thayer, 1993; Lin \& Shao, 1999; Routree \& Able, 1993, 1997). Tidal creeks are meandering channels or courses of water that are characteristic of coastal plains in large estuarine complexes of southeastern Brazil (Lana et al., 1989). These creeks drain the particulate material in suspension, as well as the products from biological and physical processes in mangroves and spartinas, exporting them into adjacent aquatic systems according to the local tidal regime (Lorenzi, 1998).

Tidal creeks are capable of profoundly influencing their surrounding environment. However, the same processes that are used to transport nutrients and organic matter into the estuaries are also capable of spreading pollutants, especially domestic waste. Not surprisingly, human populations are among the most important sources of stress to these habitats. Although the conservation of mangrove areas can contribute to the maintenance of normal nutrient levels (Pagliosa, 2004), the intense urbanization of the Brazilian coast has caused profound changes in the original condition of these ecosystems, increasing the need for effective management efforts. An emphasis on tidal creeks in conservation plans would favor both resident and migratory fish, providing a heterogeneous environment where these species can develop (Desmond et al., 2000).

In Brazil, several euhaline tidal creeks have been studied at Paranaguá Bay and other estuaries in northern Brazil (Vendel et al., 2002; Krumme et al., 2004, respectively). These studies usually indicate a predominance of few species of Tetraodontidae, Ariidae, Engraulidae, Mugilidae, Gerreidae, and Sciaenidae families in the euhaline region of the estuaries. A low diversity index (around 1), in contrast to a high richness index, in addition to a predominance of juveniles, is common to tidal creeks studied in Brazilian mangroves.

The goal of the present study is to characterize the fish community in two tidal creeks in southern Brazil, with particular emphasis on seasonal variation in species composition, providing crucial information to guide future management efforts. 


\section{MATERIALS AND METHODS}

\section{Study area}

The Pinheiros Bay and all its component channels encompass an estimated area of $59.4 \mathrm{~km}^{2}$ (Brandini, 2000). This bay is strongly influenced by coastal waters, with high levels of salinity and $\mathrm{pH}$. Two tidal creeks were chosen for the present study, one in the Ilha das Peças (2526'252"S and 481' $905^{\prime \prime} \mathrm{W}$ ) and the other in the Ilha de Superagüi (2525'259"S and 481'시"W). This is one of the most conserved areas of the South/ Southeast Brazilian coast.

\section{Data collection}

Two Fyke nets were used to block simultaneously the mouths of both tidal creeks. The nets were set up facing the creeks at the beginning of the afternoon ebb tide. Six hours later, at the trough of the lower tide, all fish were removed from the net, placed in individual plastic bags and kept on ice. The nets were then turned to collect the fish entering the creek during the night flood tide, and six hours later the respective fish were collected as previously described. The whole process was repeated monthly throughout a year, from June of 2003 to May of 2004, totaling 48 samples. Environmental data (salinity, water temperature, and $\mathrm{pH}$ ) were collected at the beginning of the ebb tide, at the trough of the ebb tide, and at the end of the night flood tide.

\section{Data analysis}

Samples from each tidal creek were grouped for the data analysis (two samples/month). Data analysis was carried out separately for each season, each of which being composed of three monthly samples, for a total of six replicates for each season. The seasons were considered as follows: winter: June, July and August; spring: September, October and November; summer: December, January and February; and fall: March, April and May. One-way ANOVA was used to compare seasonal averages of the physical-chemical parameters and number of fish.

In addition, fish communities were described using commonly used metrics: Margalef's richness index $(D=(S-1) / \log M)$ and Shannon-Wiener diversity index $\left(H^{\prime}=\right.$ $-\Sigma\left(p_{i}^{*} \ln \left(p_{i}\right)\right)$, where $S$ is the number of species in the sample, $N$ is the number of collected individuals, $p_{\mathrm{i}}$ is the proportion of the species in the total sample.

Fishes were measured (standard length, in $\mathrm{cm}$ ) and weighed $(0.01 \mathrm{~g})$. The standard length, used for analysis, corresponds to the distance from the tip of the snout to the end of the last vertebra. Gonadal development of each fish was assessed using the macroscopic observation method described by Vazzoler (1996). In this paper, juveniles are the individuals classified as the "A" stadium of gonadal maturation.
Finally, the classification of each fish species into trophic guilds was conducted based on the studies of Gay et al. (2006), Chaves \& Bouchereau (2004), Lunardon-Branco \& Branco (2003), Pedra et al. (2006), Guedes et al. (2004), Bortoluzzi et al. (2006), Cruz-Escanola (2005), Targett (1978), Benvenute (1990), Vendel \& Chaves (1998), Figueiredo \& Menezes (1978), and Menezes \& Figueiredo (1980 A,B, 1985, 2000).

The present study considered as resident those species for which all developmental stages can be frequently found within the estuaries (without necessarily being limited to those areas), whereas visitor species are occasionally found in estuaries or frequently found only during part of their lives, usually in their early developmental stages.

\section{RESULTS}

\section{Environmental parameters}

Variation in average temperature, salinity, and $\mathrm{pH}$ averages varied as expected (Fig. 1). The summer presented the highest temperature and lowest salinity values (mean $=25^{\circ} \mathrm{C}$ and 18 , respectively), whereas the winter presented lowest temperature values with highest salinity (means $=20^{\circ} \mathrm{C}$ and 28 , respectively). Spring and fall presented intermediate values. Average $\mathrm{pH}$ values were the only parameter that did not vary significantly among the seasons.

\section{Fish community}

A total of 13,755 fishes belonging to 55 species and 27 families were collected over the course of the present study (Table 1). Individuals of Anchoa parva collected between March and June accounted for more than $70 \%$ of all captures. The second most common species, Cetengraulis edentulus, accounted for $9 \%$ of the collected individuals, although its occurrence was restricted to four months. Approximately one sixth of the collected species belonged to the order Clupeiformes, although five of which were represented by less than 10 individuals. The abundance of the three most abundant species of Clupeiformes deeply affected measurements of species richness, diversity and biomass. This group is characterized by small-bodied pelagic species. However, species that were found in the 0.1 to $1 \%$ interval should not necessarily be considered as unimportant, given that this category includes several relatively largebodied species (e.g. Rypticus randalli, Cathorops spixii, Genidens genidens) that occupy high trophic levels. The species Sphoeroides testudineus accounted for a large portion of the total biomass ( $46 \%$ of the total), followed by Bairdiella ronchus (13.5\%) and A. parva (11.6\%).

The remaining species included omnivores (Cyclichthys spinosus, Eugerres brasilianus) and a few 

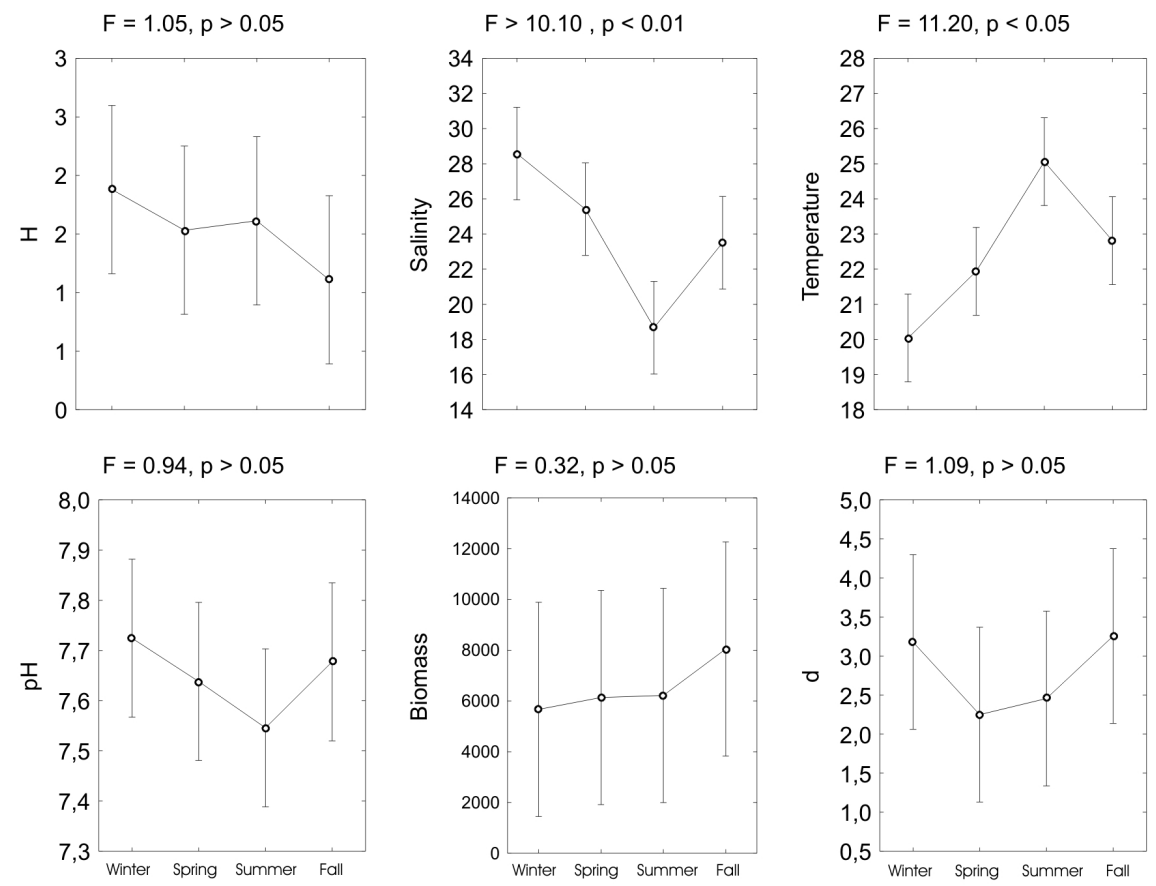

Figure 1 - Average values of salinity, temperature, $\mathrm{pH}$, biomass, and ecological indices, shown separately for each season. Statistically significant differences are only found between the averages of the abiotic data.

piscivorous (Isopisthus parvipinnis, Lycengraulis grossidens, Strongylura marina) that contributed little to either the number of individuals or biomass of their communities, except for Oligoplites saliens and Atherinella brasiliensis. Although most species and individuals collected during this study were migrants or visitant, the resident species influenced most heavily the collected biomass.

Approximately $40 \%$ of the species were collected only as juveniles, although $67 \%$ was represented by up to five individuals. The three most abundant species of Clupeiformes were predominantly juvenile individuals (79, 100 and $97 \%$, respectively) (Table 1). Mature individuals were represented mostly by $S$. testudineus and $S$. greeleyi, B. ronchus, $R$. randali, A. brasiliensis or $A$. parva. Spawned individuals were almost exclusively represented by $S$. testudineus, S. greeleyi, $A$. brasiliensis and $B$. ronchus. Only seven species were collected in all maturation stages (Table 1).

\section{Seasonal variation}

The collection of $S$. testudineus and S. greeleyi (Tetraodontidae), Cathorops spixii and Genidens genidens (Ariidae), Bairdiella ronchus (Sciaenidae) and Rypticus randalli (Serranidae), all benthophagic or epibenthonic predators, did not follow any obvious pattern throughout the year. Clupeiformes that exhibit planctophagic behavior were mainly captured during fall (Table 1). Biomass did not vary significantly among the seasons, but showed an increase of $30 \%$ in the fall when compared with biomass of other seasons (Fig. 2).

Winter collections were characterized by the presence of Isopisthus parvipinnis and Lycengraulis grossidens (Table 1), all specimens collected measured $15-20 \mathrm{~cm}$ in length. These species did not occur in expressive numbers, but they are noteworthy for their frequency in winter in relation to other seasons. The decrease in the capture of dominant species, as well as the relatively high species richness, caused the diversity during this period to be the highest during this study (Fig. 1). Winter was marked by an increase in species richness due to the exclusive and single appearance of species such as Porichthys porosissimos and Symphurus tessellatus. This season also included the collection of several juvenile sciaenids, such as Micropogonias furnieri and Stellifer rastrifer, as well as engraulids, mugilids and $C$. spinosus. The largest individuals collected during this season were Strongylura marina $(34 \mathrm{~cm})$, Ophichthus gomesii $(34 \mathrm{~cm})$ Mugil curema $(21 \mathrm{~cm})$, and Genidens genidens $(20 \mathrm{~cm})$, and they were the only representative of them respective species in the season.

The lowest number of individuals and species was recorded during the spring (Fig. 1). Even common species, such as $C$. spinosus and $A$. tricolor, were absent during this season. Four gerreid species were present, three of which were captured in a single sample. The largest individuals were $S$. testudineus $(20 \mathrm{~cm}), M$. curema $(19 \mathrm{~cm})$, and $B$. ronchus $(19 \mathrm{~cm})$. Juveniles were virtually absent during this period (Fig. 2). All dominant 
Table 1 - Proportion of maturation stages, number of individuals in each season, total of captured individuals and their biomass in the Baía de Pinheiros.

\begin{tabular}{|c|c|c|c|c|c|c|c|c|c|c|c|}
\hline Family & Species & $\% A$ & $\% B$ & $\% \mathrm{C}$ & $\% \mathrm{D}$ & Winter & Spring & Summer & Fall & $\%$ of the total & Biomass (g) \\
\hline Achiridae & Achirus lineatus & 100 & - & - & - & - & - & 1 & - & 1 & 1 \\
\hline Engraulidae & Anchoa lyolepis & 78 & 11 & 11 & - & 1 & - & - & 8 & 9 & 11 \\
\hline Engraulidae & Anchoa parva & 79 & 9 & 11 & - & 330 & 80 & 16 & 9333 & 9759 & 9.065 \\
\hline Engraulidae & Anchoa sp. & 100 & - & - & - & 1 & - & - & - & 1 & - \\
\hline Engraulidae & Anchoa tricolor & 98 & 2 & - & - & 4 & - & 6 & 44 & 54 & 39 \\
\hline Haemulidae & Anisotremus & 100 & - & - & - & - & - & - & 1 & 1 & 1 \\
\hline Atheinopsidae & Atherinella brasiliensis & 5 & 16 & 68 & 10 & 12 & 31 & 3 & 94 & 140 & 2.124 \\
\hline Sciaenidae & Bairdiella ronchus & 16 & 59 & 18 & 7 & 97 & 34 & 32 & 49 & 212 & 10.607 \\
\hline Carangidae & Caranx hippos & 100 & - & - & - & - & - & - & 1 & 1 & 34 \\
\hline Carangidae & Caranx latus & 100 & - & - & - & - & - & 1 & - & 1 & 3 \\
\hline Ariidae & Cathorops spixii & 64 & 28 & 4 & 4 & 8 & 6 & 18 & 18 & 50 & 2.053 \\
\hline Centropomida & Centropomus parallelus & - & - & - & - & - & - & - & 4 & 4 & 372 \\
\hline Centropomida & Centropomus sp. & 100 & - & - & - & - & - & 3 & 9 & 12 & 7 \\
\hline Engraulidae & Cetengraulis .edentulus & 100 & - & - & - & - & - & 6 & 1243 & 1249 & 2.849 \\
\hline Ephipiidae & Chaetodipterus faber & 100 & - & - & - & - & 1 & - & - & 1 & 117 \\
\hline Pristigasterida & Chirocentrodon & 67 & 33 & - & - & - & - & - & 3 & 3 & 2 \\
\hline Carangidae & Chloroscombrus & 100 & - & - & - & - & - & 1 & 1 & 2 & 2 \\
\hline Diodontidae & Ciclichthys spinosus & 100 & - & - & - & 2 & - & 9 & 6 & 17 & 15 \\
\hline Paralichthyida & Citharichthys arenaceus & 63 & 25 & 13 & - & 1 & 2 & 3 & 2 & 8 & 110 \\
\hline Paralichthyida & Citharichthys sp. & 100 & - & - & - & - & - & - & 3 & 3 & 0 \\
\hline Paralichthyida & Citharichthys spilopterus & 100 & - & - & - & - & - & - & 4 & 4 & 161 \\
\hline Gobiidae & Ctenogobius shufeldti & 100 & - & - & - & - & - & - & 2 & 2 & 1 \\
\hline Sciaenidae & Cynocion acoupa & - & 100 & - & - & - & 1 & - & - & 1 & 57 \\
\hline Sciaenidae & Cynocion sp. & 100 & - & - & - & - & - & - & 45 & 45 & 34 \\
\hline Gerreidae & Diapterus rhombeus & 57 & 43 & - & - & 5 & 7 & 1 & 1 & 14 & 439 \\
\hline Gerreidae & Eucinostomus argenteus & 57 & 43 & - & - & - & 16 & 2 & 3 & 21 & 390 \\
\hline Gerreidae & Eucinostomus gula & - & 100 & - & - & - & 1 & - & - & 1 & 23 \\
\hline Gerreidae & Eucinostomus & - & 100 & - & - & - & 1 & - & - & 1 & 22 \\
\hline Gerreidae & Eugerres brasilianus & - & - & $100-$ & - & - & - & - & 1 & 1 & 230 \\
\hline Ariidae & Genidens genidens & 62 & 30 & 5 & 3 & 7 & 12 & 7 & 11 & 37 & 2.466 \\
\hline Clupeidae & Harengula clupeola & 96 & - & 3 & 1 & 2 & - & 179 & 454 & 635 & 1.777 \\
\hline Hemirhamphid & Hemirhamphus & - & 33 & 67 & - & 3 & - & - & - & 3 & 29 \\
\hline Hemirhamphid & Hyporhanphus unifaciatus & 33 & 25 & 33 & 8 & 1 & 2 & 1 & 8 & 12 & 133 \\
\hline Sciaenidae & Isopisthus parvipinnis & 33 & 17 & - & 50 & 6 & - & - & - & 6 & 187 \\
\hline Engraulidae & Lycengraulis grossidens & 33 & 22 & 33 & 11 & 8 & 1 & 2 & 11 & 22 & 631 \\
\hline Sciaenidae & Micropogonias furnieri & 84 & 13 & 4 & - & 43 & 1 & 2 & $1-$ & 56 & 730 \\
\hline Mugilidae & Mugil gaimardianus & - & 50 & - & 50 & 1 & 1 & - & - & 2 & 180 \\
\hline Mugilidae & Mugil curema & 25 & 50 & 25 & - & 1 & 2 & 1 & 1 & 5 & 773 \\
\hline Mugilidae & Mugil sp. & 100 & - & - & - & 2 & 3 & - & - & 5 & 1 \\
\hline Carangidae & Oligoplites saliens & 93 & 7 & - & - & 2 & - & 151 & 1 & 154 & 2.968 \\
\hline Carangidae & Oligoplites sauros & 100 & - & - & - & - & - & - & 3 & 3 & 5 \\
\hline Ophicthidae & Ophichthus gomesii & 100 & - & - & - & 1 & - & - & - & 1 & 24 \\
\hline Clupeidae & Opisthonema oglinum & 100 & - & - & - & - & - & - & 24 & 24 & 22 \\
\hline Pristigasterida & Pellona harroweri & 100 & - & - & - & - & - & - & 2 & 2 & 9 \\
\hline Batrachoididae & Porichthys porosissimus & 100 & - & - & - & 1 & - & - & - & 1 & 1 \\
\hline Triglidae & Prionotus sp. & 100 & - & - & - & - & - & - & 1 & 1 & 0 \\
\hline Serranidae & Rypticus randalli & 4 & 58 & 38 & - & 15 & 5 & 10 & 18 & 48 & 835 \\
\hline Clupeidae & Sardinella brasiliensis & 100 & - & - & - & - & - & - & 15 & 15 & 16 \\
\hline Carangidae & Selene vomer & 100 & - & - & - & - & - & - & 2 & 2 & 73 \\
\hline Tetraodontidae & Sphoeroides greeleyi & 11 & 10 & 40 & 40 & 18 & 45 & 44 & 33 & 140 & 2.074 \\
\hline Tetraodontidae & Sphoeroides testudineus & 19 & 32 & 20 & 29 & 164 & 268 & 296 & 94 & 822 & 36.286 \\
\hline Sciaenidae & Stellifer rastrifer & 98 & - & 2 & - & 14 & 4 & - & 120 & 138 & 126 \\
\hline Belonidae & Strongylura marina & - & - & 100 & - & 1 & - & - & - & 1 & 51 \\
\hline Belonidae & Strongylura timucu & - & 100 & - & - & - & - & - & 1 & 1 & 28 \\
\hline Synoglossidae & Symphurus tessellatus & 100 & - & - & - & 1 & - & - & - & 1 & 20 \\
\hline & & & & & & 752 & 524 & 795 & 2770.922 & 13754 & 78.202 \\
\hline
\end{tabular}

species, except Rypticus randalli, showed $50 \%$ or more of total number of individuals with mature gonads (Fig. $3)$.

The number of species was still low during the summer (Fig. 2), yet clupeiforms became more representative both in number of species and individuals. Juveniles became slightly more frequent, represented by five carangid species and one centropomid species. Only one carangid species, Oligoplites saliens, was abundant, although it occurred in a single sample. Largebodied individuals were uncommon (Mugil curema -
$22 \mathrm{~cm})$. Exactly $90 \%$ of individuals of Rypticus randalli showed elevated levels of gonadal development (Fig. 3).

The fall was characterized by a dominance of individuals smaller than $10 \mathrm{~cm}$ in length (Fig. 2). The overwhelming dominance of $A$. parva, $C$. edentulus and $H$. clupeola caused diversity indexes to decrease, although the number of species was the largest recorded during the year, most of which being represented by less than ten individuals (Fig. 1). This is the case of the Pellona harroweri, Chirocentrodon bleekerianus, 

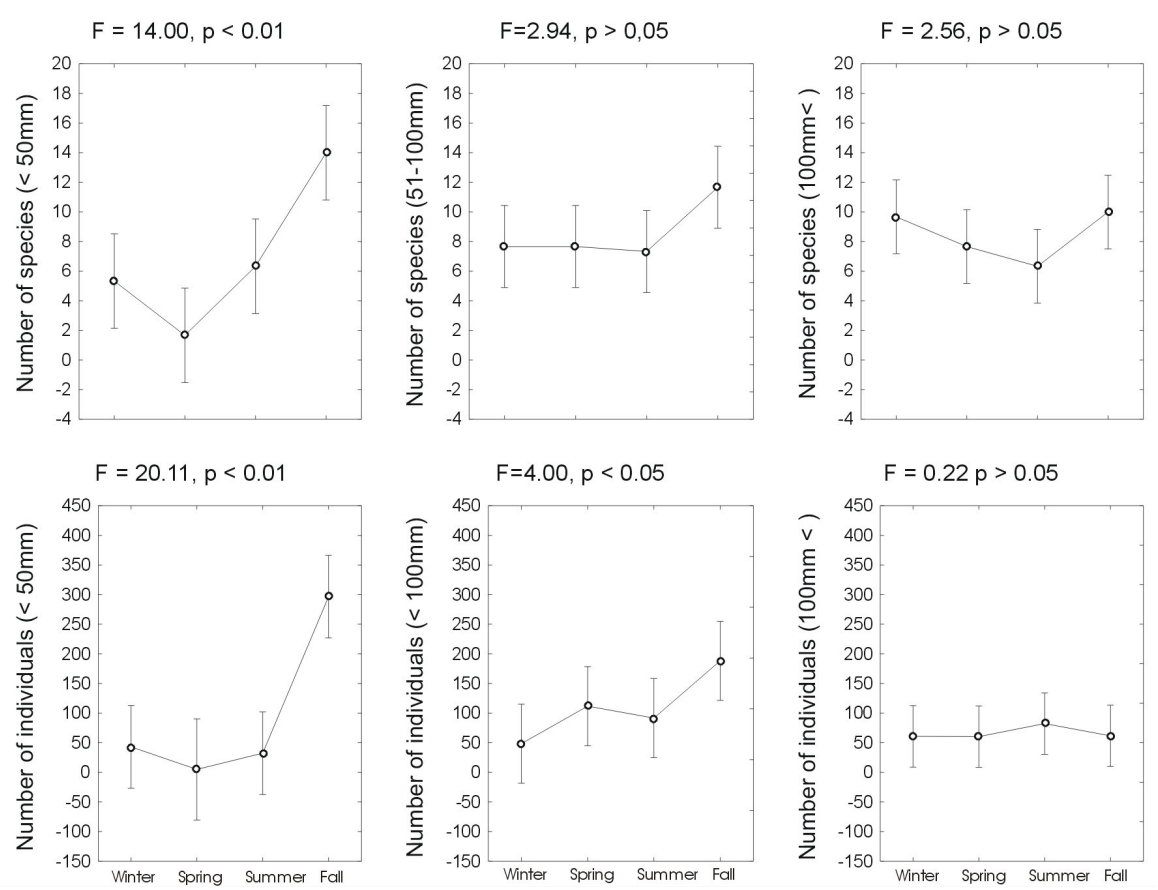

Figure 2 - Average number of species and individuals in each season, separated by size classes, showing the significant increase in small (juvenile) fish in the fall.

Sardinella brasiliensis, Opisthonema oglinum, Anisostremus surinamensis, Prionotus sp., Centropomus sp., Cytharinchthys sp., and five species of Carangidae. This season seems to be important for the juvenile stage of Cynoscion sp. and Stellifer rastrifer. Only Atherinella brasiliensis and Rypticus randalli showed mature gonads (Fig. 3). The largest fishes included $S$. timucu $(27 \mathrm{~cm})$, Centropomus parallelus $(21 \mathrm{~cm})$, and Eugerres brasilianus $(21 \mathrm{~cm})$.

\section{DISCUSSION}

The community of resident and visitor fish species associated with the studied tidal creeks was shown to be rich and diverse, particularly for this type of sampling protocol. Both typically bottom-dwelling and demersal species were abundant at the studied tidal creeks. Several trophic levels were sampled, as well as all developmental stages of some species. The diversity and richness indices were very high in some periods of the year.

Tidal creeks, as well as the mangrove areas where they are inserted, are frequently named "nurseries". The abundance of juveniles is undoubtedly high in these environments, but considering that many of the fishes that frequented the tidal creeks were late juveniles or even adults, some of them piscivorous, the term "nursery" must be used carefully. Rountree \& Able (1997) already underscored the presence not only of minnows but also of late juveniles.
The spring and part of the summer were inferred to be reproductive periods, whereas the fall and adjacent months were growth periods, dominated by immature individuals. Other studies also found similar patterns (Vendel et al., 2002; Robertson \& Duke, 1990). The spring spawning of $B$. ronchus in the mangrove channels of the Baía de Guaratuba has been reported by Chaves (1995). A. parva leaves the interior of the estuaries to spawn during the spring (Esper, 1982), but several mature individuals were captured in the tidal creeks. These results can be explained by the location of the studied tidal creeks, which were in the outer part of the bay, in areas that were close to the reproductive areas of $A$. parva. The fall recruitment leads to high richness levels during this season when compared to the spring (Vendel et al. 2002; the present study), yet the diversity indices are low due to the marked dominance of clupeiforms.

Three clupeiforms species showed the most distinct seasonal patterns, with an increase in the number of sampled individuals and species in the fall and adjacent months. The great number of individuals and biomass of few clupeiforms species in the fall were also found in several studies within and outside the Baía de Paranaguá (Gay et al., 2000; Oliveira Neto et al., 2004; Spach et al., 2004 a; Vendel et al., 2002). The species that are members of the most basal levels of the food web are the most directly favored by the increase in primary productivity that occurs in the warmest seasons of the year (Brandini \& Thamm, 1994; Spach et al., 2004 b) and they are the most dominant species 

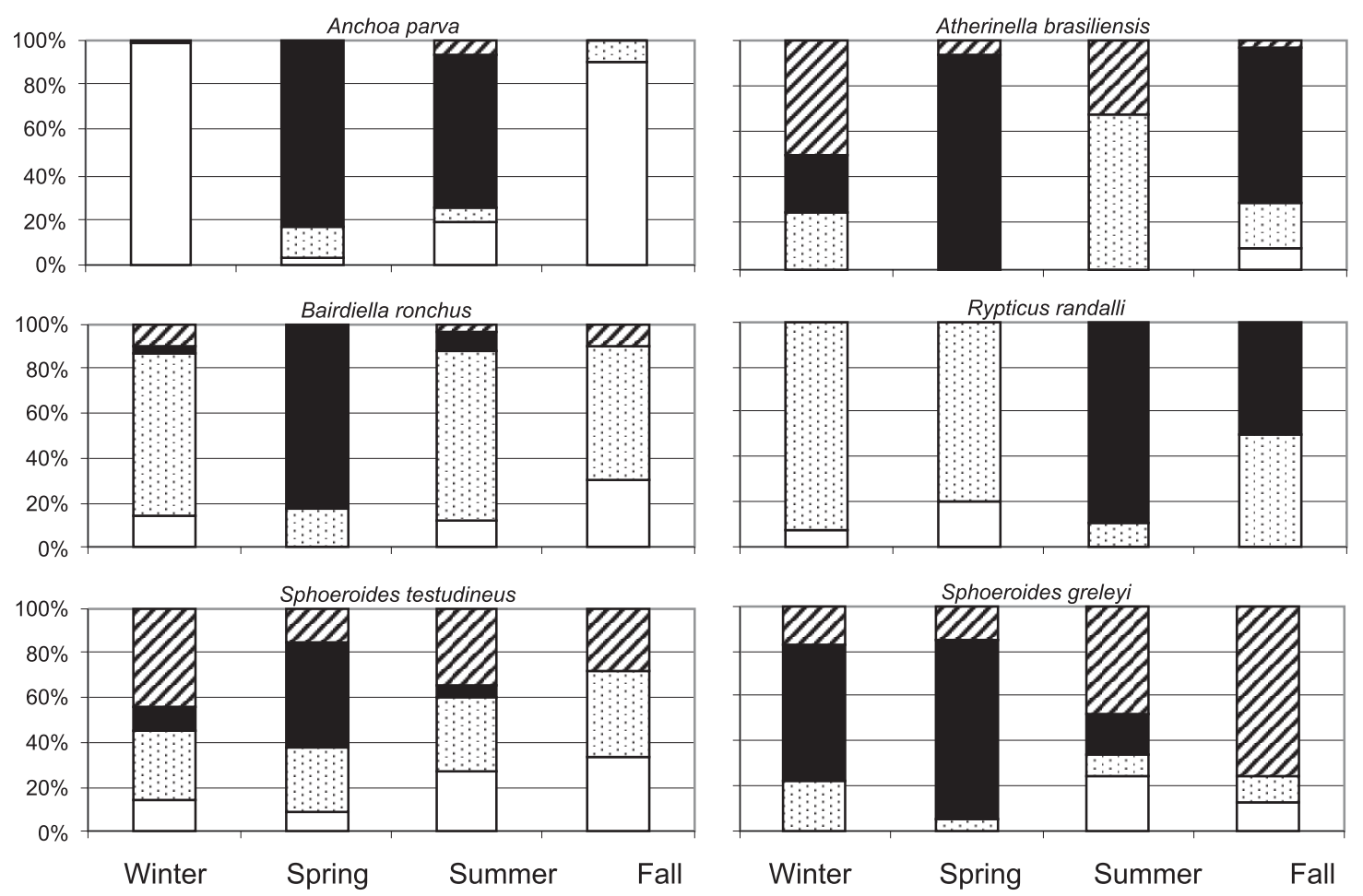

$\square$ Imature

-9 In maturation

Mature

$\square$ Spawned

Figure 3 - Proportion of maturation stages, throughout the year, of the most frequently collected species in the Baía dos Pinheiros, indicating a higher occurrence of mature individuals in the spring, except for Rypticus randalli.

in several marine environments (Barreiros et al., 2004; Blaber et al., 1984; Ross et al., 1987). This pattern was also observed in the tidal creeks of the Baía dos Pinheiros, with the dominance of $A$. parva, $C$. edentulus and, to a smaller extent, $H$. clupeola. The remaining clupeiforms were much less abundant in comparison to other studies. Similarly, the dominant clupeiform species in the Baía dos Pinheiros are not the same of those in other nearby sites. In the Baguaçú tidal creek (Baía de Paranaguá), no engraulid was equally abundant, with the most common species in that site being $C$. edentulus and $A$. tricolor. This suggests that these clupeiform species use frequently the river creeks, but the composition and the degree of dominance of the different species are very sensitive to yearly and spatial variation. An example of this complex spatial influence is the study of $C$. edentulus, which showed a strong correlation between substrate granulometry and the abundance of this species (Gay et al., 2000), even though it is a pelagic filter-feeder. Another example is A. parva, which is preferentially associated with shallow turbid water, with temperatures below $23^{\circ} \mathrm{C}$ (although they were still found at temperatures above $31^{\circ} \mathrm{C}$ ), withstanding variable salinity levels, causing them to be more abundant in the inner portion of the estuaries (Silva \& Araújo, 1999). However, this was the most abundant species in both studied tidal creeks, despite being located in the most external portions of the estuary, but still showing shallow, turbid waters with great variation in salinity and temperature. The clupeiforms are likely using the tidal creeks for protection, as observed for $A$. michilli (Reis \& Dean, 1981).

The decrease in abundance of the dominant Clupeiforms species in the tidal creeks on winter is likely due to incoming of these predators. The increase in salinity during the winter might have contributed to the increase in sciaenid abundance. The occurrence of $I$. parvipinnis is a similar pattern to that found in the Baía de Guaratuba, where this species enters the mangrove channels mainly during the fall and winter to feed on other fish, despite interannual variation (Chaves et al., 1998). Piscivorous belonging to other families, such as Lycengraulis grossidens, Strongylura marina, and Ophictus gomesi, are typically estuarine species and probably were attracted to tidal creeks to explore the abundant resource.

S. testudineus, C. spixii, G. genidens, and B. ronchus were dominant benthophagic species that showed considerable irregularity in abundance, yet were still present throughout the entire year, as seen in other regions of the same estuarine system (Godefroid et al., 1998; Oliveira-Neto et al., 2004; Spach et al., 2004; Spach et al., 2003; Vendel et al. 2002.). 


\section{CONCLUSION}

Tidal creeks are environments that are intensively visited by fish of all trophic levels and maturation stages. The richness and diversity indices are above those usually reported in the literature. The frequent engraulid capture in the fall is not coincidental, suggesting that these species seek protection in the tidal creeks.

\section{REFERENCES}

Barreiros, P.J.; Figna, V., Hostin-Silva, M.\& Santos, R.S. 2004. Diel Seasonlity of a Shallow-Water Fish Assemblage in a Sandy Beach at Canto Grande, Santa Catarina, Brazil. J. Coast. Res., special issue, n. 42.

Blaber, S.J.M.; Hay, D. G.; Cyrus, D.P. \& Martín, T.J. 1984. The ecology of two degraded estuaries on the north coast of Natal, South Africa. S. Afr. J. Zool., 19: 224-240.

Brandini, F.P. \& Thamm, C.A.C. 1994. Variações diárias e sazonais do fitoplâncton e parâmetros ambientais na Baía de Paranaguá. Nerítica, 8(1-2): 55-7.

Chaves, P. \& Bouchereau, J.L. 2004. Trophic organization and functioning of fish populations in the Bay of Guaratuba, Brazil, on the basis of a trophic contribution factor. Acta Adriatic, 45(1): 8394.

Chaves, P.T.C. 1995. Atividade reprodutiva de Bairdiella ronchus (Cuvier) (Pisces, Sciaenidae) na baía de Guaratuba, Paraná, Brasil. Rev. Bras. Zool., 12(4): 759-766.

Chaves, P.T.; Rickli, A. \& Bouchereau, J. 1998. Stratégie d'occupation de la mangrove de la baie de Guaratuba (Brésil) par le Sciaenidae prédateur Isopisthus parvipinnis (Teleostei, Pisces). Cah. de Biol. Mar., 39: 63-71.

Esper, M. L. P. 1982. Reprodução e crescimento de Anchoa januaria (Steindachner, 1879) na região de Ponta da Cruz (Baía de Paranaguá), Paraná, Brasil. Dusenia, 13(1):15-35.

Godefroid, R. S., Hofstaetter, M. \& Spach, H. L. 1998. Moon, tidal and diel influences on catch composition of fishes in the surf zone of Pontal do Sul beach, Paraná. Rev. Bras. de Zool., 15(3): 697 - 701.

Hoss, D.E. \& Thayer, G.W. 1993. The importance of habitat to the early life history of estuarine dependent fishes. Am. Fish. Soc., 14: $147-158$.

Lana, P.C.; Almeida, M.V.O.; Freitas, C.A.F.; Couto, E.C.G.; Conti, L.M.P.; Gonzales-Peronti, A.L.; Giles, A.G.; Lopes, J. S.; Silva, M.H.C. \& Pedroso, L. A. 1989. Estrutura espacial de associações macrobênticas da Gamboa Perequê (Pontal do Sul, Paraná). Nerítica, 4: 119-136.

Lin, H. J. \& Shao, K.T. 1999. Seasonal and diel changes in a subtropical mangrove fish assemblage. Bull. Mar. Sci., 65(3): 775-794.

Lorenzi, L. 1998. Composição e distribuição da macrofauna bêntica em gamboas da Baía de Paranaguá (Paraná, Brasil). Unpublished Dissertation, Universidade Federal do Paraná, Curitiba. 71 p.

Figueiredo, J.L. \& Menezes, N.A. 1978. Manual de peixes marinhos do Brasil. II. Teleostei (1). Museu de Zoologia. USP. 110p.

Menezes, N.A. \& Figueiredo, J.L. 1980 a. Manual de peixes marinhos do Brasil. III. Teleostei (2). Museu de Zoologia. USP. 89p.

Menezes, N.A. \& J.L. Figueiredo, 1980 b. Manual de peixes marinhos do Brasil. IV. Teleostei (3). Museu de Zoologia. USP. 96p.

Menezes, N. A. \& J.L. Figueiredo, 1985. Manual de peixes marinhos do Brasil. V. Teleostei (4). Museu de Zoologia. USP.

Menezes, N. A. \& J.L. Figueiredo, 2000. Manual de peixes marinhos do Brasil. VI. Teleostei (5). Museu de Zoologia. USP. 116p.

Pereira, L.E. 1994. Variação diurna e sazonal dos peixes demersais na Barra do Estuário da Lagoa dos Patos, RS. Atlântica, Rio Grande, 5-21.

Pessanha, A.L.M.\& Araújo, F.G. 2003. Spatial, temporal and diel variations of fish assemblages at two sandy beaches in the Sepetiba Bay, Rio de Janeiro, Brazil. Est. Coast. Shelf Sci., 57: 817-828.

Robertson, A.L. \& Duke, S.J.M. 1990. Mangroves as nursery sites: Comparisons of the abundance and species composition of fish and crustaceans in mangroves and other nearshore habitats in tropical Australia. Mar. Biol., 96: $193-205$.

Ross, S.T.; Mcmichael Jr., R.H \& Ruple, D.L. 1987. Seasonal and diel variation in the standing crop of fishes and macroinvertebrates from a Gulf of Mexico surf zone. Est. Coast. Shelf Sci., 391-412.

Schultz, Y.D.; Favaro, L.F. \& Spach, H.L. 2002. Aspectos reprodutivos de Sphoeroides greeleyi (Gilbert), Pisces, Osteichthyes, Tetraodontidae, da gamboa do Baguaçu, Baía de Paranaguá, Paraná, Brasil. Rev. Bras. Zool., 19(1), p.65-76.

Silva, M.A. \& Araújo, F.G. 1999. Influëncia dos fatores ambientais na estrutura de populações de manjubas (Clupeiformes-Engraulididae) na Baía de Sepetiba, RJ. Acta Biol. Leop., 21(2): 229-240.

Soares, L.S.H. \& Vazzoler, A.E.A.M. 2001. Diel changes in food and feeding activity of sciaenid fishes from the south-western Atlantic, Brazil. Rev. Bras. Biol., 61(2): 197-216. 
Spach, H.L.; Santos, C. \& Godefroid, R. S. 2003. Padrões temporais na assembléia de peixes na gamboa do Sucuriú, Baía de Paranaguá, Brasil. Rev. Bras. Zool., 20(4): 591-600.

Spach, H.L., Santos, C.; Godefroid, R. S.; Nardi, M. \& Cunha, F. 2004 b. A study of the fish community structure in a tidal creek. Braz. J. Biol., 64(2): 337351.

Vazzoler, A.E. 1996. Biologia da reprodução de peixes teleósteos: teoria e prática. Maringá: EDUEM, 169p.

Vendel, A.L.; Spach, H. L.\& Lopes, S.G. 2002. Structure and Dynamics of Fish Assemblages in a Tidal Creek Environment. Braz. Arc. Biol. Technol., 45(3): 365373.

Submetido: Dezembro/2008

Revisado: Maio/2009

Aceito: Fevereiro/2010 